\title{
Pengaruh Financial Distress Dan Ukuran Kap Terhadap Kualitas Audit
}

\author{
Rizqa Awalia Rahman \\ rizqa.rahman@act.uad.ac.id, \\ Program Studi Akuntansi, Universitas Ahmad Dahlan
}

\begin{abstract}
Abstrak
Proses bisnis yang semakin kompleks dan ditambah dengan implementasi standar akuntansi keuangan membuat peran dari Kantor Akuntan Publik menjadi sangat penting. Beberapa kasus yang melibatkan auditor dari KAP menunjukkan bahwa opini audit yang diberikan tidak mampu menunjukkan kondisi sebenarnya dari perusahaan. Padahal, audit yang berkualitas tinggi dapat menyediakan informasi dalam pengambilan keputusan oleh para pengguna laporan keuangan. Penelitian ini bertujuan untuk mengetahui apakah financial distress dan ukuran KAP berpengaruh terhadap kualitas audit serta perbedaan kualitas audit yang diberikan oleh KAP. Sampel penelitian menggunakan perusahaan BUMN yang terdaftar di Bursa Efek Indonesia dari tahun 2015 hingga 2018. Hasil penelitian menunjukkan bahwa financial distress dan ukuran KAP berpengaruh terhadap kualitas audit. Selain itu, penelitian ini menunjukkan bahwa kualitas audit yang diberikan oleh KAP Big 4 lebih baik dibandingkan KAP Non Big 4.
\end{abstract}

Kata Kunci: Perusahaan BUMN; Kualitas Audit; KAP Big 4; Financial Distress

\begin{abstract}
Business processes and accounting standards are becoming more complex. The role of public accountants is not optimal in detecting and preventing business continuity problems. The audit opinion has not been able to show the actual condition of the company. Whereas, high quality audits can provide good information in decision making by management, creditors, or investors. This study aims to examine whether financial distress and size of public accounting firm have impact to audit qualitu and using Big 4's audit service are more excellent than others. Sample in this study is Indonesia State Owned Enterprises that listed in Indonesia Stock Exchange from 2015 to 2018. We use regression test and t- test as analyses technique. We found that financial distress and size of public accounting firm influenced audit quality. We also found that Big 4 have delivered better audit quality than others.
\end{abstract}

Keywords: Indonesia State Owned Enterprises; Audit Quality; Big 4; Financial Distress 


\section{PENDAHULUAN}

Proses bisnis dan standar akuntansi menjadi lebih kompleks sehingga hal itu menuntut adanya peningkatan kualitas dari jasa audit yang diberikan oleh kantor akuntan publik (DeFond \& Zhang, 2014). Terlebih dalam kurun waktu dua tahun terakhir, perhatian masyarakat Indonesia tertuju pada kinerja laporan keuangan perusahaan-perusahaan yang bernaung dalam Badan Usaha Milik Negara (BUMN). Polemik hasil audit laporan keuangan tahun 2018 PT Garuda Indonesia dilanjutkan dengan isu gagal bayar klaim asuransi yang dialami oleh PT Jiwasraya pada tahun 2019 menjadi sebuah pertanyaan akan kinerja dari perusahaan-perusahaan BUMN dan juga kualitas audit yang diberikan oleh Kantor Akuntan Publik Big 4.

Penelitian ini terinspirasi dari kasus yang dialami oleh PT Jiwasraya. Kasus yang menimpa PT Jiwasraya berdampak langsung pada kelangsungan usaha perusahaan tersebut. Peranan akuntan publik dirasa belum maksimal dalam mendeteksi permasalahan kelangsungan usaha perusahaan. Kualitas Audit yang diwujudkan dalam opini audit belum mampu menunjukkan keadaan sebenarnya perusahaan. Audit yang berkualitas dapat memberikan masukan informasi dalam pengambilan keputusan oleh manajemen, kreditor, ataupun investor pada perusahaan-perusahaan BUMN.

Topik kualitas audit biasanya diteliti pada perusahaan swasta yang terdaftar di Bursa Efek. Penelitian-penelitian tersebut menguji faktor-faktor yang berpengaruh terhadap kualitas audit (Carey \& Simnett, 2006; Chen et al., 2008; DeAngelo, 1981; Francis, 2004; Francis \& $\mathrm{Yu}, 2009)$. Hasil penelitian terdahulu menunjukkan bahwa ukuran Kantor Akuntan Publik (KAP) berpengaruh terhadap kualitas audit (Carey \& Simnett, 2006; Chen et al., 2008; Choi et al., 2010; Francis \& Yu, 2009).

Perbedaan penelitian ini dengan penelitian terdahulu ada beberapa hal. Yang pertama ialah objek penelitian yang berupa perusahaan BUMN yang terdaftar di Bursa Efek Indonesia. Adanya perubahan image perusahaan BUMN yang dulu identik dengan bermasalah dalam tata kelola perusahaan akan tetapi sekarang memiliki kinerja yang sama bagusnya dengan perusahaan swasta (Rakhman, 2018). Hasil penelitian yang dilakukan oleh Nindita \& Siregar (2013) yang menunjukkan tidak ada pengaruh antara ukuran KAP dengan kualitas audit juga menjadi salah satu pendorong motivasi penelitian. Selain itu, penelitian ini akan menggunakan model Audit Quality Matric Score (Francis, 2004) sebagai proksi variabel kualitas audit karena masih sedikit pula penelitian di Indonesia yang menggunakan model ini.

Berdasar pada uraian di atas, peneliti ini ingin menguji pengaruh financial distress dan ukuran KAP pada kualitas audit yang dilakukan oleh Kantor Akuntan Publik pada perusahaan BUMN. Oleh karena itu, rumusan masalah yang diajukan dalam penelitian ini : Apakah financial distress dan ukuran KAP berpengaruh terhadap kualitas audit kepada perusahaan BUMN, Apakah KAP Big 4 memiliki kualitas audit yang lebih baik kepada perusahaan BUMN.

\section{TINJAUAN PUSTAKA}

\section{Badan Usaha Milik Negara (BUMN)}

BUMN memiliki peran yang penting dalam pertumbuhan negara Indonesia. Salah satu fungsi dari BUMN ialah menyediakan barang dan jasa guna kesejahteraan rakyat dengan cara memberdayakan aktivitas-aktivitas strategis milik Negara. Peran lainnya dari BUMN ialah adanya aliran dividen yang masuk dalam Anggaran Penerimaan dan Belanja Negara (APBN).

Struktur organisasi BUMN mirip dengan perusahaan swasta yang terdaftar di Bursa Efek Indonesia. Dalam meningkatkan kualitas laporan keuangan yang dimilikinya, BUMN memiliki satuan pengendalian internal dan melakukan proses audit yang dilakukan oleh pihak 
internal maupun eksternal perusahaan. Meskipun begitu, kasus manipulasi laporan keuangan dan prospek kelangsungan usaha masih sering terjadi.

\section{Financial Distress}

Kesulitan keuangan atau yang sering dikenal dengan istilah financial distress menjadi hal yang paling ingin dihindari oleh semua perusahaan-perusahaan. Financial distress didefinisi sebagai kondisi keuangan suatu perusahaan yang mengalami kekurangan kas pada sisi aset dan nilai utang yang berlebih pada sisi liabilitas ((Saji, 2018); (Altman et al., 2017); (Muñoz-Izquierdo et al., 2020)). Kekurangan aliran kas masuk berakibat pada ketidakpastian dalam memenuhi kewajiban keuangan yang dimiliki perusahaan. Berbagai model prediksi telah dikembangkan untuk mendeteksi financial distress suatu perusahaan. Altman (1968) melalui Altman's Score Model telah melakukan berbagai macam pemutakhiran model prediksi.

\section{Kualitas Audit}

Penilaian mengenai kualitas audit sangat sulit dilakukan karena proses audit melibatkan berbagai prosedur yang tidak dapat diamati dari laporan keuangan semata (DeAngelo, 1981). DeAngelo (1981) mendefinisi kualitas audit sebagai kemampuan auditor dalam menemukan kecurangan dalam laporan keuangan kemudian melaporkannya kepada manajemen. Seorang auditor berkewajiban untuk mengungkap ketidakwajaran laporan keuangan yang bermanfaat dalam mencegah terjadinya salah saji dan mendukung kelangsungan hidup perusahaan.

\section{Ukuran Kantor Akuntan Publik dan Kualitas Audit}

Kualitas audit kadang dikaitkan dengan ukuran Kantor Akuntan Publik (KAP). DeAngelo (1981) berpendapat bahwa audit yang dilakukan oleh KAP besar jauh berkualitas dibanding dengan KAP kecil karena mereka telah memiliki staff dan teknologi informasi yang lebih unggul. Hal tersebut sesuai dengan hasil penelitian yang dilakukan oleh Carey \& Simnett (2006); Chen et al. (2008); Choi et al. (2010); Francis \& Yu (2009); Guedhami et al. (2009).

\section{Model Penelitian}

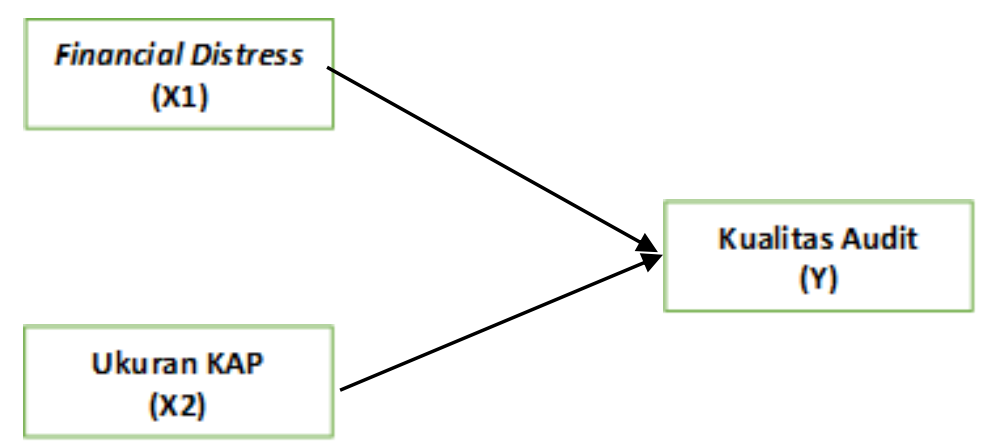

Gambar 1. Model Penelitian 


\section{METODE}

Penelitian ini merupakan penelitian kuantitatif. Variabel dependen dalam penelitian ini ialah kualitas audit, sedangkan variabel independennya ialah ukuran KAP dan financial distress. Data yang digunakan merupakan data sekunder. Populasi penelitian ialah perusahaan BUMN yang terdaftar di BEI periode tahun 2015 - 2018. Kriteria sampel ditentukan sebagai berikut: Perusahaan BUMN yang telah menyampaikan laporan keuangan yang telah diaudit periode 2015 -2018. Perusahaan BUMN yang tidak termasuk ke dalam sektor keuangan.

Tabel 1 Kriteria Sampel

\begin{tabular}{lcc}
\hline \multicolumn{1}{c}{ Kriteria Sampel } & $\begin{array}{c}\text { Tidak Sesuai } \\
\text { Kriteria }\end{array}$ & Jumlah \\
\hline \hline $\begin{array}{l}\text { Perusahaan BUMN terdaftar di BEI periode } \\
2015-2018 .\end{array}$ & 19 \\
$\begin{array}{l}\text { Perusahaan BUMN non keuangan yang } \\
\text { menyajikan laporan keuangan dan tahunan }\end{array}$ & 4 & 15 \\
secara berturut-turut dalam perioda 2015-2018. & & \\
\hline Sumber: Data Primer, diolah (2020)
\end{tabular}

Penelitian ini berfokus pada ukuran KAP, tingkat kesehatan perusahaan, dan kualitas audit. Tingat kesehatan perusahaan diukur melalui model yang disarankan oleh Altman et al. (2017).

$$
\text { Financial Distress }=6,56 \mathrm{Z}_{1}+3,26 \mathrm{Z}_{2}+6,72 \mathrm{Z}_{3}+1,05 \mathrm{Z}_{4}
$$

Keterangan:

$\mathrm{Z}_{1}=$ Working Capital/Total Assets;

$\mathrm{Z}_{2}=$ Retained Earnings/Total Assets;

$\mathrm{Z}_{3}=$ Earnings Before Interests and Taxes/Total Assets;

$\mathrm{Z}_{4}=$ Market Value of Equity Books/Book Value of Total Liabilities;

Adapun kriteria nilai Z sebagai berikut:

$Z$ " $<1,81=$ Perusahaan berpotensi mengalami kesulitan keuangan.

$1,81 \leq \mathrm{Z} " \leq 2,99=\quad$ Perusahaan berada dalam kondisi grey area .

Z" $>2,99=$ Perusahaan berada dalam kondisi sehat.

Kualitas audit diukur dengan model Audit Quality Matric Score (Francis, 2004). Kualitas audit diukur dengan Audit Quality Matric Score (AQMS) mempertimbangkan opini audit dan Audit Tenure. Model kualitas audit tersebut disesuaikan dengan ketersediaan data yang ada di Indonesia.

\section{Going Concern}

Bernilai 1, Untuk kategori going concern dan pada tahun depan perusahaan mengalami negatif arus kas operasi atau kerugian bersih, atau tidak berkategori going concern dan pada tahun depan perusahaan tidak mengalami negatif arus kas operasi atau kerugian bersih. Bernilai 0, seandainya kedua kondisi di atas tidak terjadi.

2. Audit Tenure

Bernilai 1, seandainya akuntan publik telah mengaudit perusahaan tersebut lebih dari 1 tahun dan kurang dari 4 tahun. Bernilai 0 seandainya lama mengaudit selain yang telah disebutkan sebelumnya. 


\section{Ukuran KAP}

Bernilai 1, seandainya Kantor Akuntan Publik Big 4 dan bernilai 0 selain yang telah disebutkan sebelumnya.

Dari uraian di atas, persamaan regresi yang diajukan dalam penelitian ini sebagai berikut:

$$
\text { Kualitas Audit }=\beta 0+\beta 1 \text { Financial Distress }+\beta 2 \text { Ukuran KAP }+\mathrm{e}
$$

\section{HASIL DAN PEMBAHASAN}

Analisis statistik deskriptif dilakukan untuk mengetahui gambaran awal dari sampel penelitian. Tabel 2 menunjukkan bahwa nilai rata-rata untuk variabel kualitas audit sebesar 1,97 dengan nilai deviasi standar sebesar 0,736. Variabel financial distress memiliki nilai rata-rata sebesar 3,78 dengan nilai deviasi standar sebesar 3,375. Variabel ukuran KAP memiliki nilai rata-rata 0,62 dengan nilai deviasi standar sebesar 0,490.

\section{Tabel 2 Statistik Deskriptif}

\begin{tabular}{lcc}
\hline \hline Variabel & Nilai Rata-rata & Deviasi Standar \\
\hline \hline Kualitas Audit & 1,97 & 0,736 \\
Financial Distress & 3,78 & 3,375 \\
Ukuran KAP & 0,62 & 0,490 \\
\hline
\end{tabular}

Sumber: Data Sekunder, diolah (2020)

Langkah selanjutnya ialah melakukan uji asumsi klasik. Model penelitian ini sudah memenuhi kriteria yang diajukan dalam uji asumsi klasik. Tabel 3 berikut merupakan ringkasan dari hasil uji asumsi klasik yang telah dilakukan.

Tabel 3 Uji Asumsi Klasik

\begin{tabular}{lcl}
\hline \multicolumn{1}{c}{ Alat Uji } & $\begin{array}{c}\text { Nilai / } \\
\text { Signifikansi }\end{array}$ & \multicolumn{1}{c}{ Keputusan } \\
\hline \hline Kolmogorov Smirnov & 0,407 & Data Berdistribusi Normal \\
Runs Test & 0,795 & Terbebas Autokorelasi \\
Collinearity Statistics & 0,973 & Terbebas Multikolinieritas \\
Uji Glejser & 0,105 & Terbebas Heteroskedastisitas \\
& 0,858 & \\
\hline
\end{tabular}

Sumber: Data Sekunder, diolah (2020)

Penelitian ini menggunakan uji regresi berganda dan uji beda dalam menjawab rumusan masalah yang diajukan dalam penelitian ini. Adapun hasil dari pengujian tersebut akan dijabarkan sebagai berikut:

\section{Uji Regresi Berganda}

Uji regresi berganda digunakan untuk melihat pengaruh dari variabel-variabel independen terhadap variabel dependen. Tabel 4 berikut menunjukkan hasil dari uji regresi berganda. 
Tabel 4 Hasil Uji Regresi Berganda

\begin{tabular}{lcc}
\hline \multicolumn{1}{c}{ Variabel } & Koefisien & Nilai Signifikansi \\
\hline \hline Konstanta & 1,120 & $0,000^{* * *}$ \\
Financial Distress & 0,070 & $0,002^{* *}$ \\
Ukuran KAP & 0,942 & $0,000^{* * *}$ \\
\hline
\end{tabular}

Sumber: Data Sekunder, diolah (2020)

Keterangan:

$* * \quad=$ signifikansi pada tingkat 0,05

$* * * \quad=$ signifikansi pada tingkat 0,00

Hasil uji regresi berganda menunjukkan bahwa variabel independen dalam penelitian ini yakni financial distress dan ukuran KAP berpengaruh terhadap kualitas audit. Variabel financial distress bernilai signifikan pada tingkat 0,002 dengan nilai koefisien sebesar 0,070. Variabel ukuran KAP juga bernilai signifikan pada tingkat 0,000 dengan nilai koefisien sebesar 0,942. Tabel 5 berikut menunjukkan nilai Adjusted $R$ square sebesar 0,412 yang memberi arti variabel independen dalam penelitian ini hanya mampu menjelaskan $41,2 \%$ dari variabel dependen.

Hasil penelitian ini mendukung penelitian-penelitian sebelumnya yang menyatakan bahwa ukuran KAP berpengaruh terhadap kualitas audit (Carey \& Simnett, 2006; Chen et al., 2008; Choi et al., 2010; Francis \& Yu, 2009). Akan tetapi hasil ini tidak mendukung penelitian (Nindita \& Siregar, 2013) yang menunjukkan hasil bahwa ukuran KAP tidak berpengaruh terhadap kualitas audit karena kualitas antara KAP Big 4 dan KAP Non Big 4 dianggap cukup seragam.

\section{Uji Beda}

Uji beda dilakukan guna memperkuat hasil pengujian regresi berganda sebelumnya. Uji beda yang digunakan ialah Independent Sample test. Ringkasan hasil pengujian ditunjukkan pada tabel berikut.

Tabel 6 Hasil Uji Beda

\begin{tabular}{|c|ccc}
\hline \multirow{3}{*}{ Kualitas Audit } & Ukuran KAP & Nilai Rata-rata & Nilai Signifikansi \\
\cline { 2 - 4 } & Big 4 & 2,30 & \multirow{2}{*}{$0,000^{* * *}$} \\
& Non Big 4 & 1,43 & \\
\hline
\end{tabular}

Sumber: Data Sekunder, diolah (2020)

Keterangan:

$* * * \quad=$ signifikansi pada tingkat 0,00

Tabel 6 menunjukkan bahwa nilai rata-rata kualitas audit yang diberikan oleh KAP Big 4 lebih besar dibanding KAP Non Big 4. Hasil uji beda juga menunjukkan bahwa selisih kualitas tersebut bernilai signifikan pada tingkat 0,00 sehingga hasil tersebut juga mendukung hasil uji regresi berganda. Dapat diambil kesimpulan bahwa KAP Big 4 memiliki kualitas audit yang lebih baik dibandingkan dengan KAP Non Big 4. Hasil tersebut juga mendukung hasil uji regresi dan penelitian-penelitian sebelumnya yang menjadi rujukan dalam penelitian ini. 


\section{KESIMPULAN}

Penelitian ini memberikan bukti bahwa variabel financial distress dan ukuran KAP berpengaruh terhadap kualitas audit yang diterima oleh perusahaan BUMN. Hubungan arah antara variabel independen dan dependen ialah positif. Artinya, perusahaan yang mengalami kondisi financial distress akan mendorong peningkatan kualitas audit yang diberikan oleh Kantor Akuntan Publik. Terlebih lagi, kantor akuntan publik yang tergolong ke dalam Big 4 memiliki kualitas audit yang lebih baik dibandingkan dengan yang lain. Perbedaan tersebut disebabkan karena kemampuan sumber daya manusia dan teknologi informasi yang dimiliki. Hasil penelitian ini juga mendukung hasil penelitian-penelitian terdahulu meskipun objek yang diteliti berbeda. Hal tersebut disebabkan karena struktur perusahaan BUMN yang terdaftar di Bursa Efek Indonesia sama dengan perusahaan swasta lainnya.

\section{Saran dan Keterbatasan}

Penelitian selanjutnya diharapkan mengambil jangka waktu data yang lebih panjang. Penambahan jangka waktu diharapkan bisa menangkap fenomena-fenomena yang tidak tertangkap dalam penelitian ini. Selain itu, penambahan variabel independen lainnya sangat mungkin karena nilai Adjusted $R$ Square penelitian ini masih sebesar $41,2 \%$. Keterbatasan dalam penelitian ini ialah 1) jangka waktu penelitian hanya empat tahun dengan jumlah data sebanyak 60,2 ) model penelitian hanya memiliki nilai Adjusted $R$ Square sebesar $41,2 \%$ sehingga masih terdapat variabel-variabel yang berperan tetapi tidak masuk ke dalam model penelitian.

\section{DAFTAR PUSTAKA}

Altman, E. I. (1968). Financial Ratios, Discriminant Analysis and the Prediction of Corporate Bankruptcy. The Journal of Finance, 23(4), 589-609.

Altman, E. I., Iwanicz-Drozdowska, M., Laitinen, E. K., \& Suvas, A. (2017). Financial Distress Prediction in an International Context: A Review and Empirical Analysis of Altman's Z- Score Model. Journal of International Financial Management \& Accounting, 28(2), 131-171. https://doi.org/10.1111/jifm.12053

Carey, P., \& Simnett, R. (2006). Audit Partner Tenure and Audit Quality. The Accounting Review, 81(3), 653-676. https://doi.org/10.2308/accr.2006.81.3.653

Chen, C.-Y., Lin, C.-J., \& Lin, Y.-C. (2008). Audit Partner Tenure, Audit Firm Tenure, and Discretionary Accruals: Does Long Auditor Tenure Impair Earnings Quality? Contemporary Accounting Research, 25(2), 415-445. https://doi.org/10.1506/car.25.2.5

Choi, J.-H., Kim, F., Kim, J.-B., \& Zang, Y. (2010). Audit Office Size, Audit Quality and Audit Pricing. 43.

DeAngelo, L. E. (1981). Auditor size and audit quality. Journal of Accounting and Economics, 3(3), 183-199. https://doi.org/10.1016/0165-4101(81)90002-1 
DeFond, M., \& Zhang, J. (2014). A review of archival auditing research. Journal of Accounting and Economics, 58(2-3), 275-326. https://doi.org/10.1016/j.jacceco.2014.09.002

Francis, J. R. (2004). What do we know about audit quality? The British Accounting Review, 36(4), 345-368. https://doi.org/10.1016/j.bar.2004.09.003

Francis, J. R., \& Yu, M. D. (2009). Big 4 Office Size and Audit Quality. The Accounting Review, 84(5), 1521-1552. https://doi.org/10.2308/accr.2009.84.5.1521

Guedhami, O., Pittman, J. A., \& Saffar, W. (2009). Auditor choice in privatized firms: Empirical evidence on the role of state and foreign owners. Journal of Accounting and Economics, 48(2-3), 151-171. https://doi.org/10.1016/j.jacceco.2009.08.003

Muñoz-Izquierdo, N., Laitinen, E. K., Camacho-Miñano, M., \& Pascual-Ezama, D. (2020). Does audit report information improve financial distress prediction over Altman's traditional $Z$-Score model? Journal of International Financial Management \& Accounting, 31(1), 65-97. https://doi.org/10.1111/jifm.12110

Nindita, C., \& Siregar, S. V. (2013). Analisis Pengaruh Ukuran Kantor Akuntan Publik Terhadap Kualitas Audit di Indonesia. Jurnal Akuntansi dan Keuangan, 14(2), 91-104. https://doi.org/10.9744/jak.14.2.91-104

Rakhman, F. (2018). Can partially privatized SOEs outperform fully private firms? Evidence from Indonesia. Research in International Business and Finance, 45, 285-292. https://doi.org/10.1016/j.ribaf.2017.07.160

Saji, T. G. (2018). Financial Distress and Stock Market Failures: Lessons from Indian Realty Sector. Vision: The Journal of Business Perspective, 22(1), 50-60. https://doi.org/10.1177/0972262917750244 